\title{
AHEAD OF THEIR TIME
}

NICOLÁS STUTZIN

Profesor, Facultad de Arquitectura, Arte y Diseño

Universidad Diego Portales, Santiago, Chile

\section{Keywords}

Future

Past

Present

History

Transcendence
We usually understand magazines as news repositories, publishing what we do not yet know and is important to see. But they are not just that. A magazine can also rescue something from the past and bring it into a present discussion. Or it can honor what should have been known but was not appreciated in its time. The following selection presents the cases when $A R Q$ magazine took this last option.

\/ e could assume that a project ahead of its time is one capable of showing us what the future might look like or how the present could have been. But in retrospect, a project ahead of its time is not only one that brings us closer to science fiction. Perhaps, it is equally avant-garde to be the project which time, humbly, has proven right.

From this viewpoint, when an architecture magazine considers that a project meets the necessary conditions to be published years or decades after being conceived 
(or executed) it is likely that we are in the presence of one of these specimens that were ahead of their time and that could only be assimilated retrospectively.

Either way, critics, editors, and academics have ignored them, either for lack of interest, lack of vision or lack of the tools necessary to judge them and to decide the place they deserved.

With this premise, I delved into $A R Q$ magazine's indexes in search of those issues where the editors have given a project belated recognition. It is the assembly of a series that rescues and praises projects vindicated or revisited years after and that, framed in later disciplinary discussions, regained considerable relevance. Whether they were first published late or republished as part of debates that turned them contemporary once again - either under alternative points of view or in the light of new precedents that showed interesting features previously ignored - these are projects that were able to transcend their time: ten visionary projects which time would have validated. Otherwise, what would be the point of publishing them (late)? ARQ 

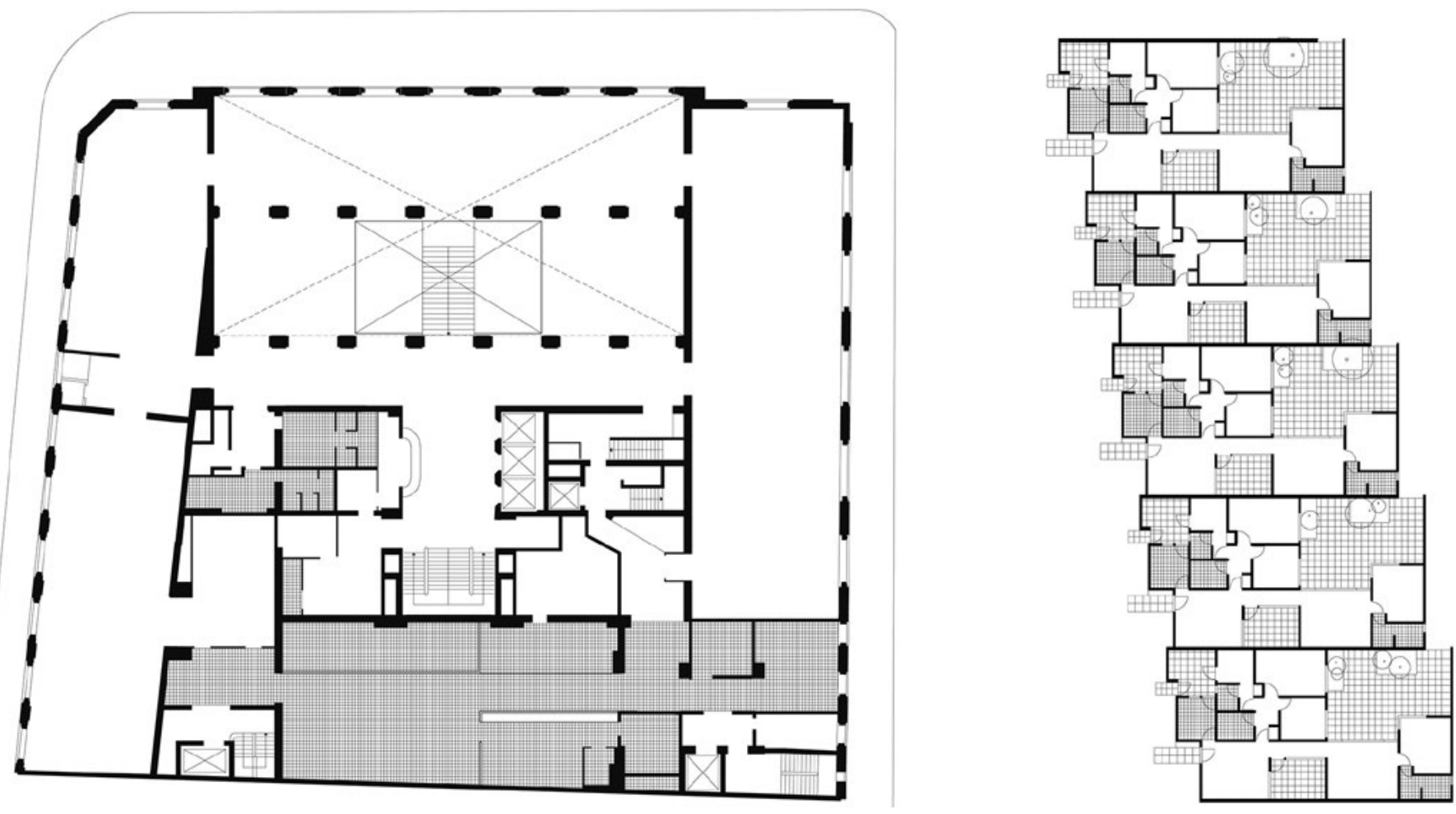

HOTEL CARRERA

QUINTA MICHITA

Josué Smith del Solar, José Smith Miller

1940

Publicado en / Published in

ARQ 58 (diciembre, 2004): 52-55

Publicado 70 años después, incluido

dentro de una revisión de plantas

notables en la historia de la arquitectura

chilena. / Published 70 years later, included

in a review of remarkable plans in the

history of Chilean architecture. 

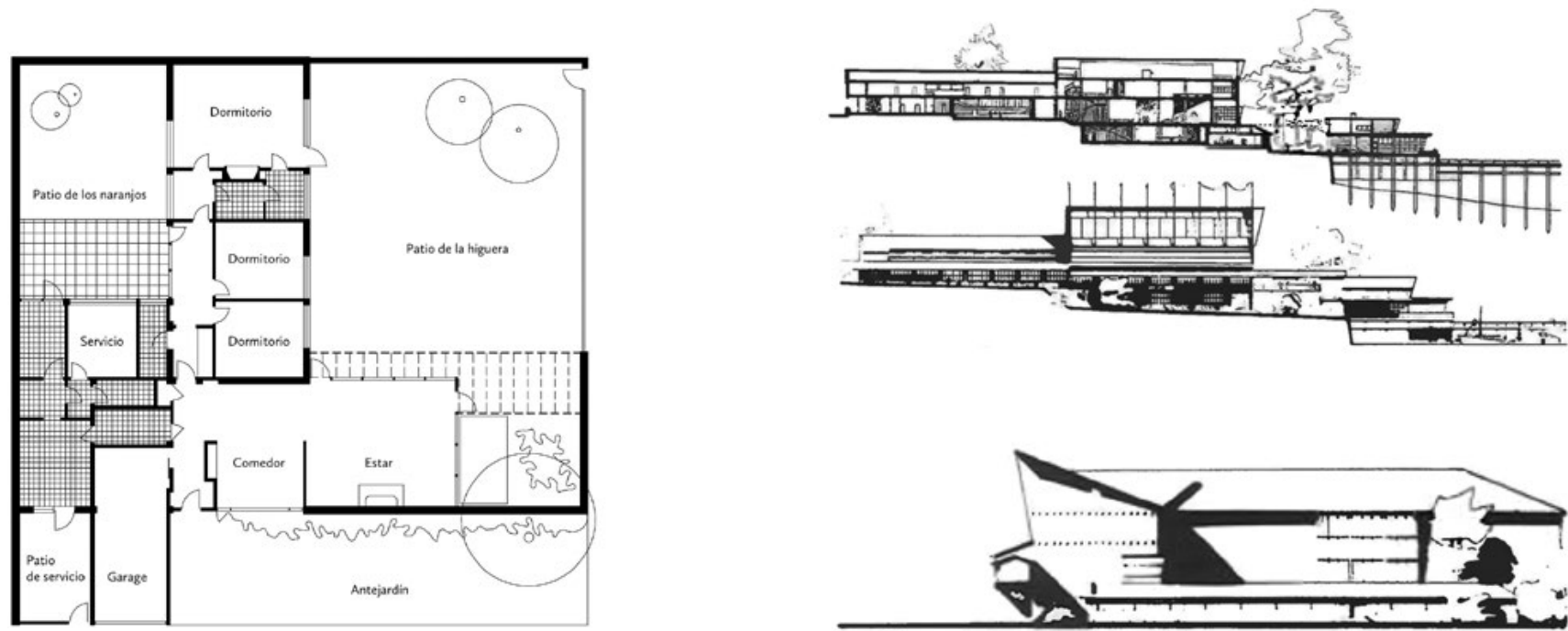

\section{CASA DUHART}

UNA BASE PESQUERA EN LA BAHÍA DE SAN QUINTÍN

1949

Publicado en / Published in

ARQ 58 (diciembre, 2004): 29

Publicada 58 años después, incluido dentro de una revisión de plantas notables en la historia de la arquitectura chilena. / Published 58 years later, included in a review of remarkable plans in the history of Chilean architecture.

Emilio Duhart (Profesor guía / Advisor: Sergio Larraín G.M.)

Publicado en / Published in ARQ 23 (mayo, 1993): 8-11

Publicada 53 años después revisando las enseñanzas de un proyecto de título en un número dedicado a la arquitectura en madera en Chile. / Published 53 years later, in reviewing the lessons of a studio project in an issue devoted to wooden architecture in Chile. 

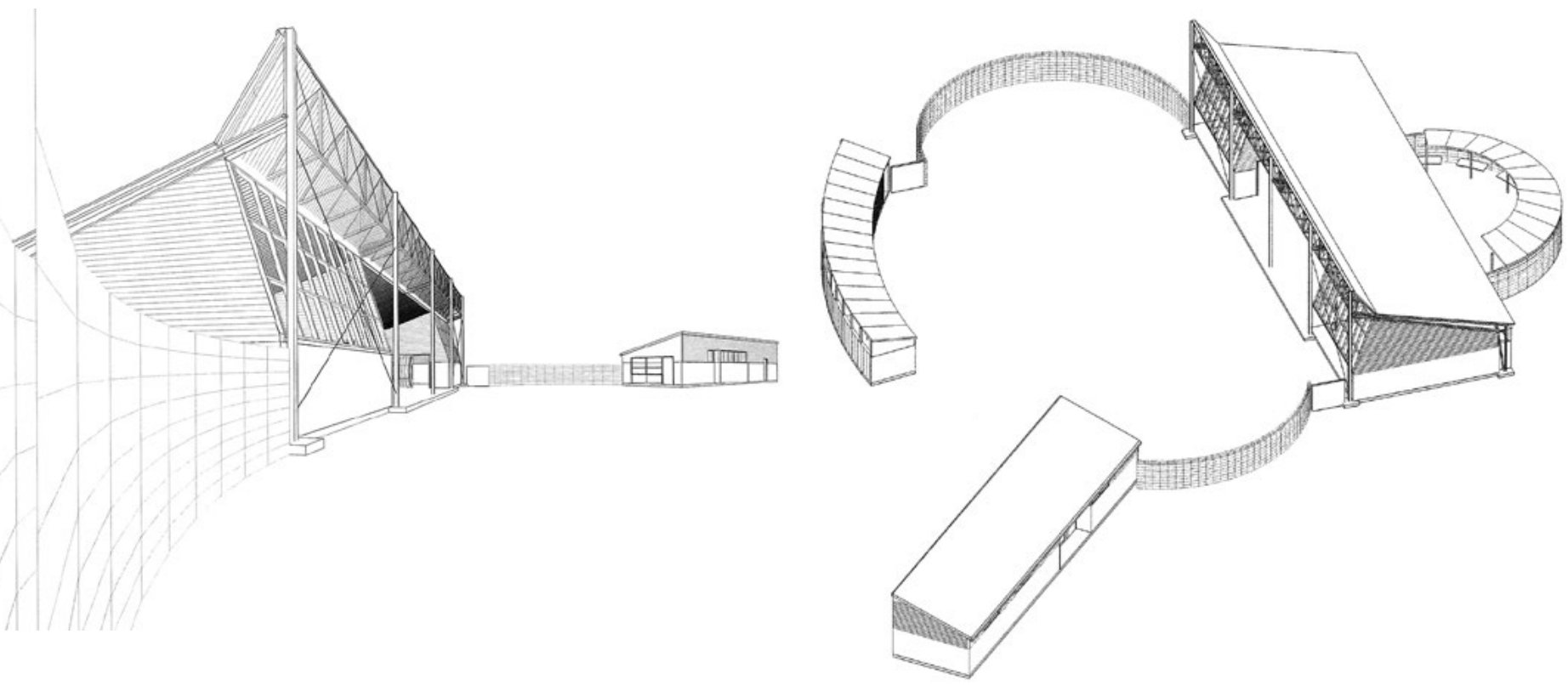

CASA PEÑA EN COLINA

Miguel Eyquem

1981

Publicado en / Published in ARQ 6 (noviembre, 1981): $\mathrm{s} / \mathrm{n}$ ARQ 41 (abril, 1999): 25-29

Publicada 22 años después proponiendo nuevas lecturas de la obra. / Published 22 years later suggesting new readings for the work.

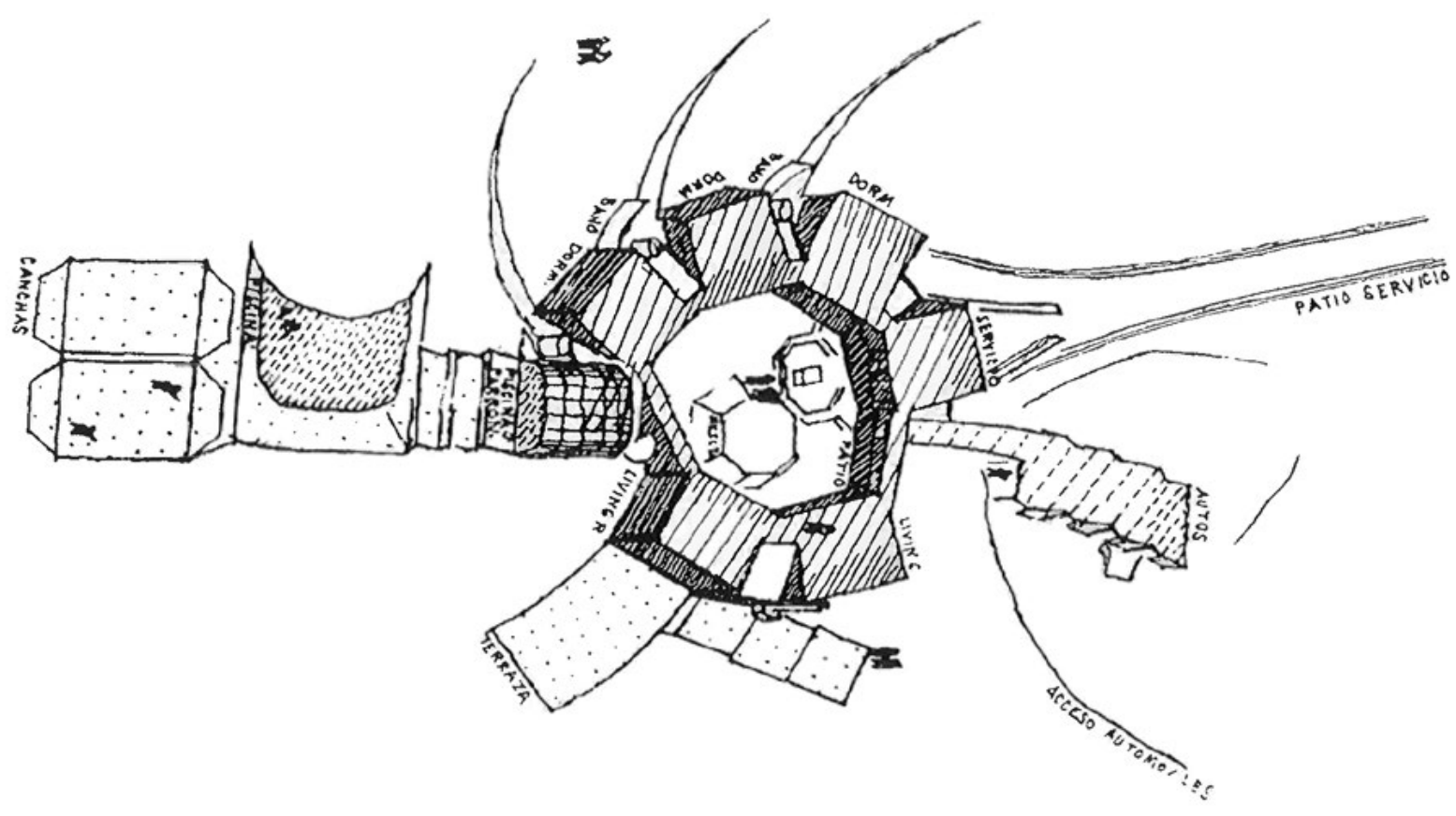


ESCUELA RURAL, LONGOTOMA

Cristián Valdés

1964

Publicado en / Published in

ARQ 56 (marzo, 2004): 46-51

Publicada 41 años después en un

número sobre edificios educacionales,

recuperando su valor contemporáneo. /

Published 41 years later in an issue on

educational buildings, reassessing its

contemporary value.

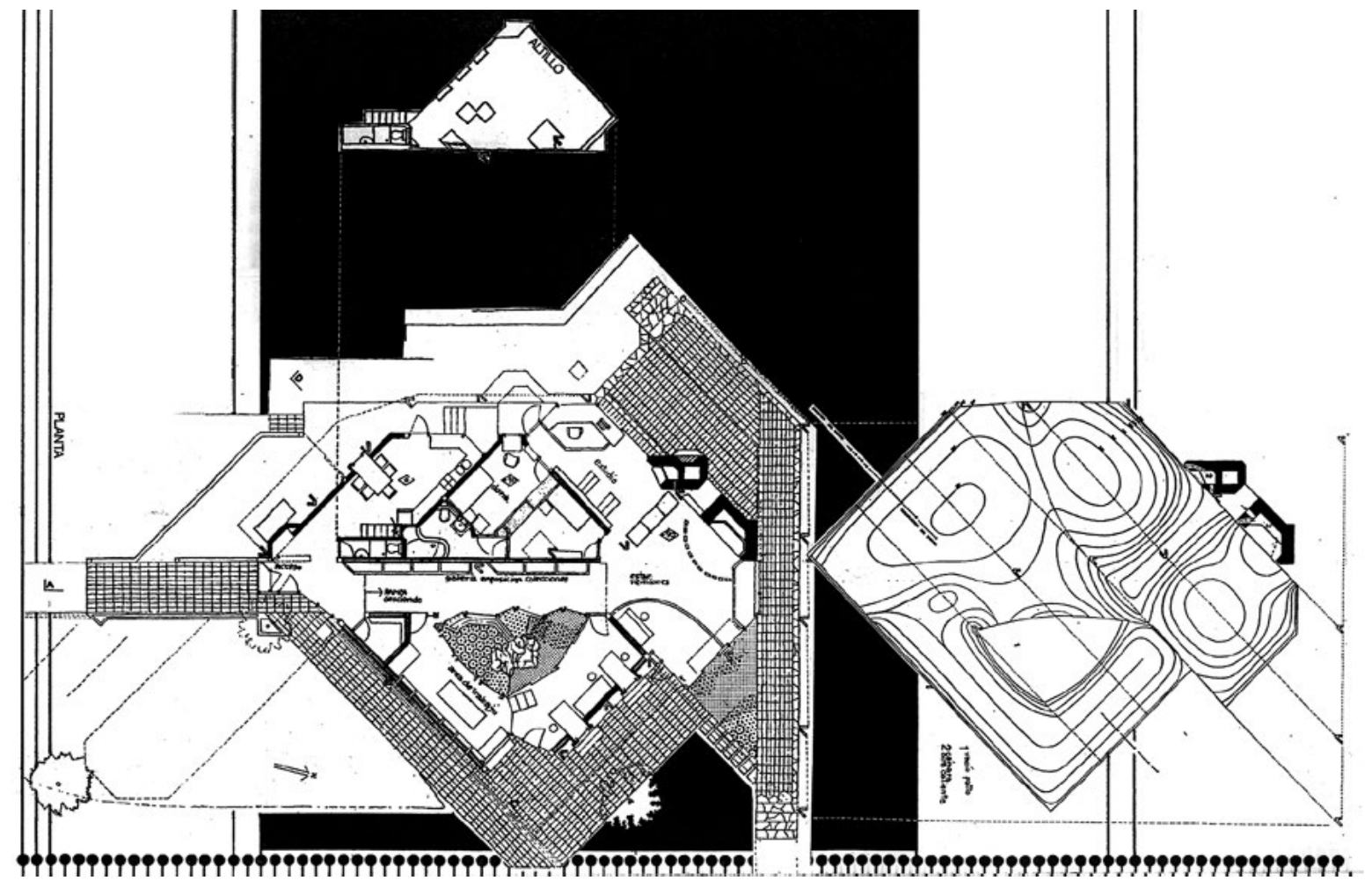

CASA OLIVETTI EN SANTIAGO

Alberto Cruz, Miguel Eyquem

1973

Publicado en / Published in

ARQ 47 (marzo, 2001): 16-21

Publicada 28 años después en un número

dedicado a la intuición en el diseño

arquitectónico. / Published 28 years

later in an issue dedicated to intuition in

architectural design. 


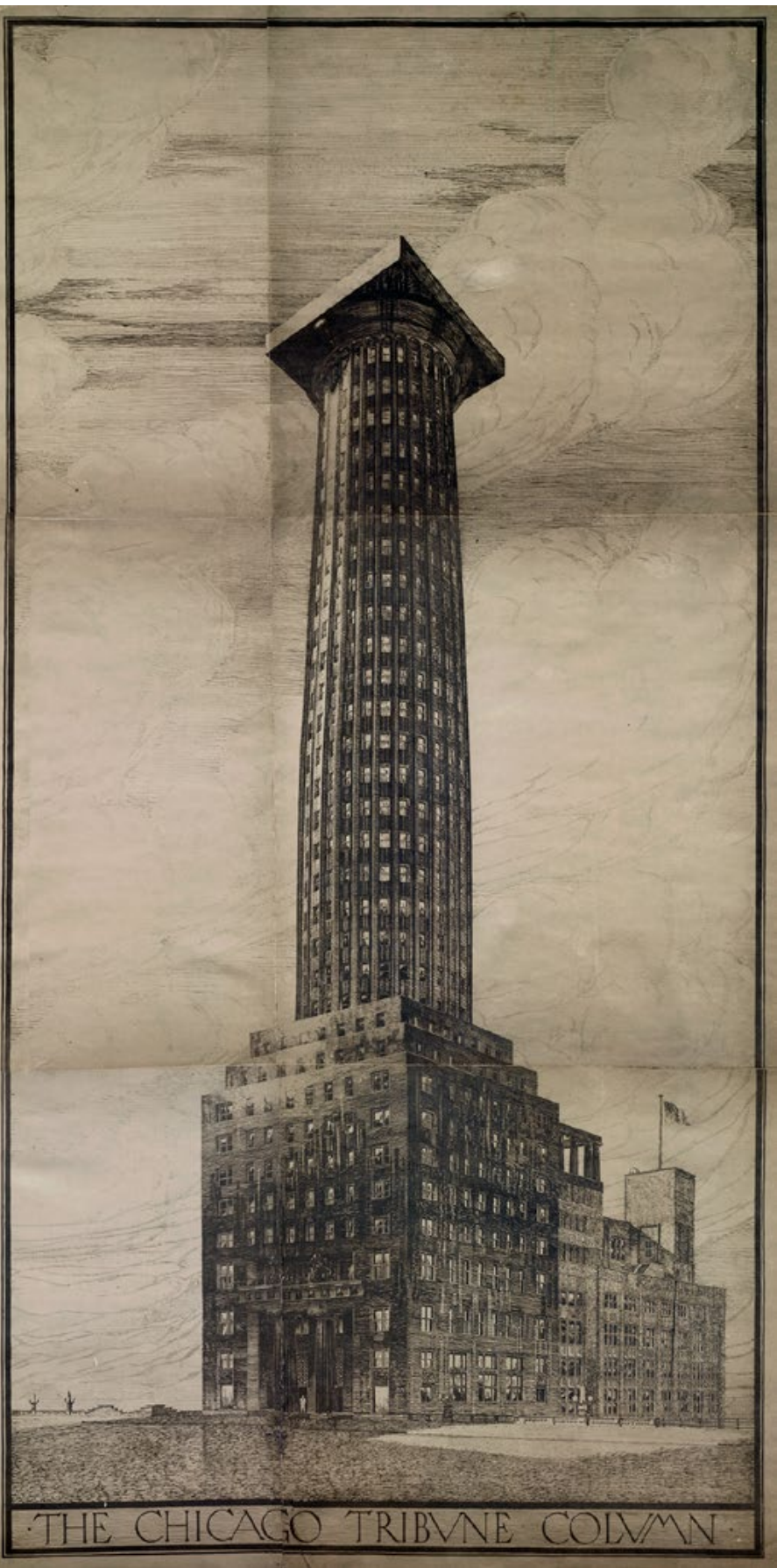

\section{CHICAGO TRIBUNE}

Adolf Loos

1922

Publicado en / Published in ARQ 95 (abril, 2017): 46-51

Publicado 95 años después revisando la tradición del uso de referentes en la arquitectura moderna. / Published 95 years later in reviewing modern architecture's tradition of using references.

Architect, Universidad de Chile, Chile (2006), Master of Science in Advanced Architectural Design and Diploma in Advanced Architectural Research, Columbia University, USA (2011). Associate Professor at the School of Architecture, Universidad Diego Portales and Assistant Professor at the School of Architecture, Pontificia Universidad Católica de Chile. 